\title{
Opinions and Recommendations of Academics Training Special Education Teachers About Applicability of Integration in Turkey
}

\author{
Mehmet INCE ${ }^{1} \&$ Ahmet YIKMIŞ ${ }^{2}$ \\ ${ }^{1}$ Dede Korkut Faculity of Education, Kafkas University, Kars, Turkey \\ ${ }^{2}$ Faculity of Education, Bolu Abant Izzet Baysal University, Bolu, Turkey \\ Correspondence: Mehmet INCE, Dede Korkut Faculity of Education, Kafkas University, Kars, Turkey.
}

Received: May 10, $2021 \quad$ Accepted: July 25, $2021 \quad$ Online Published: October 27, 2021

doi:10.5539/ies.v14n11p54

URL: https://doi.org/10.5539/ies.v14n11p54

\begin{abstract}
This study aims to state the opinions and recommendations of academics who train special education teachers for integration applications. The study is patterned as a descriptive case study, and the participants consist of 28 faculty members from 18 universities who work in the special education undergraduate program and whose professional experience ranges from 5 to 45 years. The study data were collected through face-to-face interviews with participants using the semi-structured interview technique. The obtained data were analyzed through descriptive analysis. The findings show that most academics think that integration is not being applied today and that there is a lack of necessary infrastructure for its application. Faculty members participating in the study stated that teachers do not receive adequate training about integration, teachers should undergo serious in-service training, and courses related to special education should be introduced in all departments of the faculty of education. For successful integration, it is necessary to make physical and educational arrangements, provide support education services, train teachers to have an integration perspective and improve their attitudes. In conclusion, integration is an application that can only be realized with the joint effort of all parties through multidimensional discussions of its contents.
\end{abstract}

Keywords: integration, inclusion, special education, academic, case study

\section{Introduction}

Regardless of individual differences, one of the most critical needs of individuals with disabilities is education (Yilmaz \& Batu, 2016). Education systems are primarily based on children with standard competence and understanding. In these systems, classes, textbooks, tools and materials, teaching strategies, methods, and techniques are presented as a standard to meet the needs of children with typical development, and children are considered normal to the extent they comply with these standard traits (Kirk, 1989; as cited in Ataman, 2017). Although education systems are standardized, it is clear that all children belonging to the same age group have characteristics that are distinguishable from others. Some are energetic, and some are calm; some students learn fast, and some learn slowly. Nevertheless, these individual differences do not prevent an individual from performing vital activities and receiving education in general education classes (Metin, 2012). It seems there are two ends to the education of children with disabilities: segregated education and co-education. Segregated education is the education provided by special education personnel within the framework of special programs according to the type and level of the student's disability. Co-education means students with disabilities are educated alongside students with normal development by regular classroom teachers (Batu \& Kircaali-Iftar, 2007). Special education services are provided for individuals with disabilities to benefit from general education, just like their typically developing peers. Special education is a kind of education that allows gifted children to maximize their capacity in accordance with their abilities, prevents disability from becoming an obstacle, and equips people with disabilities with skills that will aid them to integrate with society and become independent, productive individuals by making them self-sufficient (Ataman, 2003). Another definition defines special education as the education given in special environments with specially prepared content, special materials, and special teaching techniques (Zigmond \& Kloo, 2017). Educational environments where individuals with disabilities continue their education are listed in the literature from the most restrictive to the least restrictive as follows; home/hospital schools, boarding schools and institutions for special needs, special needs day institutions, special education classes, partial inclusion, and full inclusion (Ataman, 2003; Cavkaytar, 2018; Colak, 2019; Melekoglu, 2018; 
Odluyurt, 2019; Salend, 2008). The least restrictive educational environment is recommended for the education of individuals with disabilities (Batu \& Kircaali-Iftar, 2007; Melekoglu, 2018; Salend, 2008). The least restrictive educational environment aims to meet the needs of a person with disabilities at the highest level by having them coexist with their peers (Salend, 2008).

From the 1960s until the 1990s, inclusion applications for individuals with disabilities have been in the form of the least restrictive educational environment. Since the 1990s, the concept of integration has gained popularity with the search for an education program that would encompass all children's education (Thomas et al., 2001; Zeybek, 2015). One of the most important developments regarding inclusive education is the Conference on Education for All in 1990 and the Salamanca Statement published in 1994. At this conference, an integrating approach to education for all was developed and it was desired to ensure that the necessary political steps were taken for schools to provide education services to all children, especially children with special needs. At the end of the conference, the Salamanca Statement was adopted within the framework of the principles, policies, practices and activities of special education (UNESCO, 1994). Additionally, the Convention on the Rights of Persons with Disabilities and its Additional Protocols was accepted at the United Nations Headquarters in New York on December 13, 2006 and were opened for signature on March 30, 2007. The Convention attracted 82 signatories, the Optional Protocol has 44 signatories, and the Convention had one ratification. That's the most people that have ever signed a UN Convention on the first day. It is the first comprehensive human rights treaty of the twenty-first century, as well as the first human rights convention open to regional integration organizations for signature. The Convention became effective on May 3, 2008. "The Convention follows decades of work by the United Nations to change attitudes and approaches to persons with disabilities. It takes to a new height the movement from viewing persons with disabilities as "objects" of charity, medical treatment and social protection towards viewing persons with disabilities as "subjects" with rights, who are capable of claiming those rights and making decisions for their lives based on their free and informed consent as well as being active members of society" (UNESCO, 2006). Inclusion is an education that provides special education support services to students with disabilities in general education classrooms (Kargin, 2009; Vaughn et al., 2000). On the other hand, integration is an educational model that advocates that the best educational environment for all children with disabilities is the general education classroom and that they should receive the support they need in the classroom with no separation from their peers (Nichols \& Sheffield, 2014; Solis et al., 2012; Sucuoglu, 2006). International conventions made it obligatory for our country to switch to integration (Ataman, 2017). The Circular Order on Education Applications Through Inclusion/Integration updated in 2017 expresses integration's purpose and emphasizes the concept of integration by stating, "The purpose of education through inclusion/integration is to ensure that individuals with special education needs interact with other individuals of all types and levels and achieve their educational goals at the highest level."

Walker (1995) states the differences between inclusion and integration applications as follows; (a) inclusion addresses the needs of students with disabilities, while integration addresses the needs of all students; (b) inclusion adapts the student to the school, while integration adapts the school to the student; (c) inclusion considers the benefit of the students with disabilities, while integration considers the benefit of all students; (d) inclusion offers formal education with professional special education experts, while integration provides informal support education with inclusion teachers; (e) inclusion uses special education and therapies for students with disabilities, while integration advocates a good education for all students (as cited in Thomas, Walker \& Webb, 2001). In this context, one can say that integration is a philosophy and an approach that is more inclusive and aims to meet the needs of all children.

Hammeken (2000) states the following regarding the contributions of integration: Integration can improve the existing education. Adaptations and changes made for students with disabilities through integration can also be beneficial to students with typical development. Integration applications make students more moderate and sensitive to others. Students learn to accept individual differences. Integration encourages collaboration. Students with disabilities and students with typical development work together and share knowledge to achieve general education goals. Integration is a law, not a temporary trend. It creates a partnership between school staff and families by combining experience and knowledge. Integration will ensure the formation of an advanced education system for all. According to Hammeken (2000), most educators strongly advocate that students with disabilities belong to the class and believe that they have a right to equal and fair education with their peers. It is necessary to combine the general education and special education system that has existed for many years. This process is slow and does not occur automatically. Although integration is an effective application in accelerating this process, it requires time, energy, willingness to change, and the belief that integration education is the best application for all students. 
All parties of integration must have faith and willingness, along with a positive attitude. The parties who need to cooperate for integration to be successful are listed as follows; classroom teacher, school administration, school counselor, special education teacher, family, field teachers, student peers, and other experts (Gümüşkaya, 2018). Integration in which special education methods are carried out by a team that values "teamwork", which is a special education principle, becomes successful (Baykoç, 2018). However, an integration that does not consider the country's resources, environmental conditions, and the individual's disability level will most likely bring more harm than good (Civelek, 1991). In this context, it is important to take the opinions and suggestions of the team members listed above.

Literature shows that the studies on integration are mainly carried out with teachers. Along with studies examining the general acceptance levels (Saloviita, 2020) and attitudes of teachers (Desombre et al., 2019; Hernandez et al., 2016; Robinson, 2017), there are studies in our country that listen to teachers' opinions about integration (Ketenoglu Kayabaş1, 2020), studies that investigate the metaphors on integration made by teachers working in primary and secondary schools (Gürsoy et al., 2019), and studies in which administrators, teachers, students with disabilities and families evaluate integration applications (Saygın, 2015). There are also some studies that evaluate the support provided to individuals with disabilities within the framework of integration applications (Keser, 2016), studies that examine teacher competencies within the scope of integration (Keser \& Düzkantar, 2019), and studies that examine social acceptance levels of children with disabilities and children with typical development in pre-school integration environments (Bakkaloglu et al., 2020). In their research, Derzhavina et al. (2021) aimed to examine the characteristics of inclusive education and to identify ways to increase quality. Their research shows that for consumers of education services, an important obstacle to improving the quality of inclusive education is the orientation of the education system to results, not the education process. It has been revealed that the main functions of the mainstreaming school are educational, career-oriented, educational and integrative. It has been shown that relationships with teachers are an important psychological stress factor in inclusive classrooms. Inclusive classrooms were found to be far enough away from interaction with the local community. Teachers have been shown to lack teamwork and teacher's confident behavior skills in the presence of another adult in the classroom. It turned out that the inclusive school is currently characterized by a high level of internal unity but does not focus on external relations with the local community. Unlike students, parents pay attention to the creation of an accessible environment only for certain categories of children with disabilities (including children with musculoskeletal disorders), but not for children with sensory impairments (vision and hearing). Bredtmann et al. (2021) analyzed whether it affects the educational success and social integration of non-native speakers. At the end of their research, they concluded that depending on the density of non-native speakers, the degree of language diversity did not have a negative effect on students' language and math skills but worsened the social integration of non-native speakers. In their research, Okech et al. (2021) aimed to evaluate the factors affecting the effective implementation of inclusive education, taking into account learners with disabilities and other special needs. His research has focused on the following key aspects that directly affect the implementation of inclusive education: inclusive policies, attitudes, perceptions, curriculum issues and the learning environment. At the end of their research, they found that attitudes towards students with disabilities and other special needs have been increasingly positive over the past decade. In the findings regarding the abilities and abilities of learners with disabilities and other special needs to benefit from inclusive education, some participants reported that they were learners who could benefit from inclusive environments, while others reported that they could not. In terms of curriculum, it revealed that some students with disabilities and other special needs can benefit from the regular curriculum, while others can benefit from a special curriculum. Finally, with regard to environmental factors, research has revealed that adequate preparations are always made to provide an environment conducive to learning in inclusive educational settings. However, it is necessary to determine certain points such as physical and educational arrangements, regulation, teacher training programs, the contributions of integration, and expectations and suggestions of the integration's parties. In this context, the opinions of academics who train special education teachers are essential. Because legal regulations, teacher training programs, implemented programs, and road maps are formed and applied under the scientific work of academics. Therefore, there is a belief that in order for integration to succeed in our country, we must consult academics and hear their opinions. This need brings out the necessity of a study such as this.

With the findings obtained in this study, academics who train special education teachers will reveal their opinions and recommendations regarding the current situation and future state of integration in our country. The study anticipates that they will voice their opinions regarding what kind of physical adaptations a successful integration requires, what is expected from senior staff, academics, families, and teachers, what type of supportive education services are necessary, what are the benefits of integration, and their thoughts on legal regulations. This will guide what kind of teacher is necessary for integration applications and pioneer new studies that may meet these needs. 
The opinions and recommendations of academics who train special education teachers for integration applications in Turkey will also contribute to the literature.

The study aims to examine the opinions and recommendations of academics who train special education teachers for integration applications. For this purpose, the following questions were asked to the academics who train special education teachers.

1) What is your opinion on the current and future state of integration applications?

2) What are the similarities and differences between the concepts of integration and inclusion?

3) What are some positive or negative effects of integration applications?

4) What does integration contribute to students with typical development and students with disabilities?

5) What is the scope and adequacy of academic studies on integration?

6) What is your opinion on teacher adequacy and teacher training programs related to integration applications in Turkey?

7) What is your opinion on legal regulations for integration applications?

8) How do support education services affect the integration process?

9) What educational and physical adaptations our schools can apply for a successful integration?

10) What are your expectations and recommendations for integration to be successful in our country?

\section{Method}

\subsection{Research Pattern}

This study uses a descriptive case study pattern, one of the qualitative research methods, to determine the opinions and recommendations of academics who train special education teachers about integration applications. The qualitative case study allows researchers to examine in-depth the data obtained through participant observations and in-depth interviews when they need to grasp, discover and interpret a particular situation regarding an existing phenomenon or event (Glesne, 2015; Yıldırım \& Şimsek, 2018). Also, qualitative researches are studies performed when a subject need to be discovered, and they provide individuals with the opportunity to express and talk about their experiences (Creswell, 2013).

\subsection{Study Group}

According to Glesne (2015), your questions as a researcher should enable participants who know what you do not know to start talking. An effective and successful interview requires a clearly expressed research topic, interview questions that explain the research topic, and open-minded and knowledgeable participants. Following Glesne's "open and knowledgeable" idea, the study participants were selected through purposeful sampling. In a purposeful sample, the researcher uses their judgment about who will be selected and chooses the most suitable ones for the research (Balci, 2018). Accordingly, 80 academics from 20 universities with doctorate degrees in special education were contacted, considering academics have the broadest knowledge about integration. The research was conducted with 28 academics, 11 being Assistant Professors, 11 Associate Professors, and 6 Professors out of 80 academics. The academics' names are coded as A1, A2, A3...A28 with numbers that follow the interview order to prevent exposing their names and institutions. Table 1 shows information about the faculty members participating in the study. 
Table 1. Demographic information of participants

\begin{tabular}{|c|c|c|c|c|c|c|}
\hline No & Code & Gender & Title & Scientific Work & $\begin{array}{l}\text { Lectures on } \\
\text { Integration }\end{array}$ & Professional Experience \\
\hline 1 & A1 & M & Prof. Dr. & No & No & 27 years \\
\hline 2 & A2 & M & Assoc. Dr. & Books and Articles & No & 26 years \\
\hline 3 & A3 & $\mathrm{F}$ & Asst. Prof. & No & Yes & 24 years \\
\hline 4 & A4 & $\mathrm{F}$ & Assoc. Dr. & No & No & 32 years \\
\hline 5 & A5 & M & Asst. Prof. & No & No & 6 years \\
\hline 6 & A6 & M & Prof. Dr. & $\begin{array}{c}\text { Book Chapter and Thesis } \\
\text { Consultancy }\end{array}$ & No & 31 years \\
\hline 7 & A7 & $\mathrm{F}$ & Prof. Dr. & No & Yes & 27 years \\
\hline 8 & A8 & $\mathrm{F}$ & Assoc. Dr. & $\begin{array}{c}\text { Book Chapter, Project, Article, } \\
\text { Thesis Consultancy }\end{array}$ & Yes & 21 years \\
\hline 9 & A9 & $\mathrm{F}$ & Assoc. Dr. & Article, Project & Yes & 20 years \\
\hline 10 & A 10 & $\mathrm{~F}$ & Asst. Prof. & No & No & 18 years \\
\hline 11 & A11 & M & Asst. Prof. & No & Yes & 14 years \\
\hline 12 & A12 & M & Asst. Prof. & No & No & 19 years \\
\hline 13 & A13 & M & Assoc. Dr. & Article, Project & Yes & 17 years \\
\hline 14 & A14 & M & Asst. Prof. & No & Yes & 8 years \\
\hline 15 & A 15 & M & Prof. Dr. & Article & No & 44 years \\
\hline 16 & A 16 & $\mathrm{~F}$ & Assoc. Dr. & Book Chapter & No & 20 years \\
\hline 17 & A17 & M & Asst. Prof. & Article, Declaration & Yes & 9 years \\
\hline 18 & A18 & M & Asst. Prof. & No & No & 20 years \\
\hline 19 & A19 & M & Assoc. Dr. & Article & Yes & 15 years \\
\hline 20 & A20 & $\mathrm{F}$ & Asst. Prof. & Article, Book Chapter & No & 23 years \\
\hline 21 & A 21 & $\mathrm{~F}$ & Asst. Prof. & Article & Yes & 5 years \\
\hline 22 & A22 & $\mathrm{F}$ & Assoc. Dr. & Article, Project & Yes & 15 years \\
\hline 23 & A 23 & M & Prof. Dr. & $\begin{array}{c}\text { Book, Article, Thesis Consultancy, } \\
\text { Project }\end{array}$ & No & 31 years \\
\hline 24 & A24 & $\mathrm{F}$ & Assoc. Dr. & Declaration & No & 27 years \\
\hline 25 & A 25 & $\mathrm{~F}$ & Assoc. Dr. & No & Yes & 22 years \\
\hline 26 & A26 & M & Assoc. Dr. & No & No & 20 years \\
\hline 27 & A27 & $\mathrm{F}$ & Asst. Prof. & No & Yes & 16 years \\
\hline 28 & A28 & $\mathrm{F}$ & Prof. Dr. & No & No & 26 years \\
\hline
\end{tabular}

As Table 1 suggests, 14 of the participant academics are women, and 14 are men. All the academics involved in the study have doctoral degrees in special education. The work experience of the academics in special education ranges from 5 to 44 years. 7 participants do not have any publications related to integration. Of the other 23 participants, 13 are carrying out an integration course at the undergraduate level. 4 participants have written book chapters on integration, and 2 participants have written books on integration. 10 participants have articles on integration. 3 academics have been thesis supervisors on integration, and 2 academics presented papers at various congresses. 5 academics have participated in various integration projects.

\subsection{Data Collection Tools}

This study uses semi-structured interview technique, which is one of the qualitative research data collection techniques (Yıldırım \& Şimşek, 2018). In semi-structured interviews, if the interviewer has received an answer to a question during the interview process, he or she may not ask that question again or ask additional questions based on the participant's feedback. It is similar in its form to a semi-structured conversation (Balaban Sal1, 2015).

Preparation of semi-structured interview form. 20 interview questions were prepared by examining the literature and taking into account the purpose of determining the opinions and recommendations of academics who train special education teachers regarding integration. After the questions were ready, a professor with works on integration, inclusion, and measurement, an assistant professor, and a graduate linguist were consulted to examine content, structure, and language. Following the feedback from experts, the interview questions that were agreed upon were selected, and the interview form took its final form.

Pilot interviews. A pilot application was made with an associate professor working in special education to 
experiment with the questions prepared to collect research data, and the questions took their final form. The academic who participated in the pilot interview is not included in the scope of the research. At the end of the pilot application, no changes were made to the questions, as it was evident that the questions were easily understood and answered by the participant.

\subsection{Data Collection and Analysis}

The researcher carried out data collection between 6 November 2019 and 6 December 2019 through one-on-one interviews. The duration of interviews varied between $14 \mathrm{~min} .43 \mathrm{sec}$. $-63 \mathrm{~min} .51 \mathrm{sec}$., resulting in an average of 32 minutes. The researcher stated that they would ask the participants 12 semi-structured questions in order, and if there was a point that required an explanation, they could claim it. The researcher also explained that the interviews would be recorded with a voice recorder to minimize interruption and analyze the obtained data. They thanked all participants, who had given their written and verbal permissions, for their contributions to the study by participating in the interviews.

The data obtained by the semi-structured interview technique were analyzed through descriptive analysis, one of the qualitative data analysis methods. The data obtained in the descriptive analysis may be arranged according to the themes of the study questions or can be presented by taking into account the questions and aspects used in the interview and observation processes (Yıldırım \& Şimşek, 2018). At the first stage of data analysis, the interviews were redacted, all the transcripts and audio recordings were submitted to an expert opinion to ensure the accuracy of the data. After the comparison, the consistency of the transcripts and sound recordings was approved. Codes were created after all interviews were written and checked. The data were coded independently by the researcher and a special education specialist. Consensus categories were determined based on the results, and the level of reliability for the categories created for each sub-problem was determined. The reliability level of the study was determined to be $95 \%$ in the calculation made using the formula [Reliability $=$ Consensus/Consensus + Dissensus developed by Miles and Huberman (1994).

Yildirim and Simsek (2018) emphasized that some strategies such as long-term interaction, depth-focused data collection, participant confirmation, and expert review can be used to ensure validity and reliability. In this study, an expert review was applied for validity and reliability. An expert review can be attained in two ways. The first is a meeting between the expert and the researcher. At this meeting, the researcher verbally explains all the processes to the expert. $\mathrm{He} / \mathrm{she}$ evaluates the validity of his/her approach and way of thinking together with the expert by presenting the data he/she has collected and the results. The expert asks questions about the process, reviews raw data and its analysis. He/she provides feedback on the suitability of processes. In the second way, the researcher sends all the documents related to the research pattern, their analysis, and the written results to an expert, including all the raw data he/she has collected. The expert gives feedback by examining the work (Yildirim \& Simsek, 2018). In this context, following the completion of the research, an appointment was made with an expert with studies in special education and qualitative research for the validity and reliability study. All processes were presented to the expert verbally, and the necessary explanations were made through the presentation of the studies. At the end of the meeting, the expert confirmed that the research pattern, analysis, and data collection techniques are appropriate.

\section{Results}

At the end of the data analysis, the opinions of the academics involved in the research were collected under 13 main themes. Table 2 and Table 3 presented below includes participants' opinions on the central theme of the research, "Opinions on the current and future state of integration applications." 
Table 2. Academics' opinions on the current state of integration

\begin{tabular}{llc}
\hline Sub-Themes & Code & $\mathrm{f}$ \\
\hline \multirow{2}{*}{ Problems Based on Physical Conditions } & The physical infrastructure is insufficient & 6 \\
& Large student numbers & 6 \\
\hline Conceptual Issues & There is a misconception & 7 \\
\hline \multirow{3}{*}{ Staff-Related (Teachers) Issues } & Teachers have no knowledge of disability groups & 8 \\
& Integration is not implemented in a qualitative sense & 28 \\
& Even inclusion is not fully implemented & 8 \\
& There are problems with student admissions & 6 \\
\hline \multirow{3}{*}{ Application-Related Issues } & Integration is difficult to implement in the conditions of our country & 5 \\
& There are deficiencies in support education & 3 \\
& It is not possible due to the lack of program-based measurement & 1 \\
& It is not applied because the authorities are not delegated at the school & 1 \\
\hline \multirow{2}{*}{ Positive opinions } & We are in a good position today & 1 \\
& It is applied for some disability groups & 1 \\
\hline
\end{tabular}

As seen in Table 2, almost all academics stated that integration is not applied properly. Regarding the physical conditions, A27 has stated, "I do not believe integration is applicable with the current infrastructure. ... There is no infrastructure. Since there is no infrastructure, I do not believe that it can be applied, at least not in a successful way." A1 stated the following about the conceptual problems, "First of all, I have many questions about what integration really is. I mean, I have yet to fully understand where the concept of integration comes from and what it conveys. Do we mean inclusion when we say integration, or do we mean everyone benefits from equal educational rights, or is it about children getting education alongside their peers? I am not exactly sure which one we actually mean." A13 stated the following about the staff, "For now, I think the most important obstacle is that teachers in general education, that is, classroom teachers, have little or no knowledge about individuals with disabilities and how they should be educating them." A10 stated the following about application "...today integration is just inclusion with a different name. We changed the name but have not changed our methods. As for its application, I have not observed it being done. That is our current situation." A17, one of the two academics who had optimistic opinions, has stated, "Our current applications are quite better than where we were 10 years ago. We are especially in a good place about the admissions of these children to schools and their legal rights. However, that doesn't mean it's enough."

Table 3. Expectations and recommendations of academics on the future state of integration

\begin{tabular}{lll}
\hline Sub-Themes & Code & $\mathrm{f}$ \\
\hline \multirow{2}{*}{ Recommendations for physical arrangements } & Buildings should undergo physical arrangements and become physically accessible & 8 \\
& Material needs to be adapted & 2 \\
\hline & There should be measurement and evaluations based on the program & 2 \\
& Adaptations on teacher programs & 2 \\
Recommendations on educational arrangements & Academic support & 1 \\
& Teaching methods and techniques should be adapted & 1 \\
& The education system needs to change completely & 9 \\
& Each school should assign a special education teacher & 9 \\
Recommendations on support education & We must change the teacher training program & 1 \\
& There should be in-class support & 8 \\
\hline \multirow{2}{*}{ Recommendations on teacher training } & Attitudes must change & 4 \\
& Teachers need to be prepared by training & 3 \\
\hline & It can be implemented with a strong economy & 7 \\
& Can be applied step by step & 2 \\
Other & Utopian & 1 \\
& Individuals with disabilities should become more visible in our lives & 1 \\
\hline
\end{tabular}


Table 3 shows the participants' recommendations about the physical and educational regulations, support education, and teacher training. A3 has stated the following about physical and educational regulations, "There need to be physical arrangements. The physical and academic adjustments should be made in accordance with the type and level of disability." A10 has stated the following on support education, "As for the assignment of special education teachers spreading to all schools, integration indeed requires all schools to have special education teachers." A27 stated the following on teacher training, "As a preparation for future, all university teacher training programs should include classes on integration. We need to include integration not only in the special education teachers' classes but also field and classroom teachers' classes as well." A1 has expressed that integration is a utopian ideal, "An ideally integrated education is utopian."

Tables 4 and 5 show the participants' opinions on the central theme of "Opinions on the similarities and differences between the concepts of integration and inclusion."

Table 4. Academics' opinions on the differences between the concepts of integration and inclusion

\begin{tabular}{llc}
\hline Sub-Themes & Code & $\mathrm{f}$ \\
\hline \multirow{5}{*}{ The environment must be adapted to the child } & 10 \\
& Includes all disability groups & 10 \\
& Is community-based & 6 \\
& The child is the major member & 5 \\
& The environment should be suitable for every child & 4 \\
& Curriculum should be suitable for all & 2 \\
& Materials must be adapted to the student & 2 \\
& Teaching includes adaptations & 1 \\
& Defends right to fair education & 1 \\
& The school has the authority & 1 \\
& Methods and techniques are adapted to the student & 1 \\
& Education is adapted to the child & 1 \\
& Supports go to the child & 1 \\
\hline \multirow{5}{*}{ Inclusion } & Includes moderate intellectual disability & 10 \\
& The child must be adapted to the environment & 10 \\
& Is school-based & 6 \\
& Has the least restrictive educational environment & 5 \\
& The child is a guest & 5 \\
& Program includes adaptations & 1 \\
& The central administration has the authority & 1 \\
\hline
\end{tabular}

Table 4 shows the academics' discussions about the differences between the concepts of inclusion and integration in many areas such as the teaching environment, the perspectives of the individuals with disabilities, the curriculum, and the support services. A10 stated the following on these differences, "In inclusion, we include milder types of disability in classrooms, without regarding the level or type of disabilities, but in integration, disability level is not important, everything, all services are offered to the child."A15 has stated, "Even though we adapt the program and educate the child in the general education class, we call it inclusion... In inclusion, we adapt the education program to enable the child to achieve the goals."A26 has stated, "In integration, you do not separate the child from the environment, but applications such as resource room in inclusion does separate the child from the environment." A24 has stated, "Inclusion is mostly for children with mild disabilities, meaning children who do not differ much from their peers in appearance, with no severe disabilities and behavioral problems." 
Table 5. Academics' opinions on the similarities between the concepts of integration and inclusion

\begin{tabular}{llc}
\hline Sub-Themes & Code & $\mathrm{f}$ \\
\hline \multirow{5}{*}{ Inclusion and integration } & All children are in the same environment & 17 \\
& Defend education rights & 4 \\
& Defend universal design & 1 \\
& Use science-based applications & 1 \\
& Have in-class support education & 1 \\
& Are based on individual differences and requirements & 1 \\
& Are built on apparent disabilities & 1 \\
\hline \multirow{2}{*}{ Other } & Inclusion is a path that leads to integration & 9 \\
& I'm not sure if I understand the difference between them & 2 \\
\hline
\end{tabular}

Table 5 shows that many of the participants emphasized that children are in the same environment in both inclusion and inclusion practices. Regarding the inclusion and integration applications, A8 has stated, "It's actually all about being together. The individual with disabilities is together with their peers in the same environment." A25 has stated, "What I mean is that inclusion is a path that leads to integration.

Table 6 presented below, includes participants' opinions on the central theme of the research, "Opinions on the positive or negative effects of integration practices."

Table 6. Academics' opinions on the positive and negative effects of integration

\begin{tabular}{|c|c|c|}
\hline Sub-Themes & Code & $\mathrm{f}$ \\
\hline \multirow{5}{*}{ Integration's contributions to the society } & Social acceptance increases as society gains a new point of view & 14 \\
\hline & Today's children will not be discriminating when they grow up & 4 \\
\hline & Integration is a sign of development & 3 \\
\hline & We can raise productive individuals & 3 \\
\hline & Best practice for our culture & 1 \\
\hline \multirow{3}{*}{ Integration's contributions to the family } & Families of children with disabilities feel normal and good & 6 \\
\hline & Families' burdens are reduced & 6 \\
\hline & Families' quality of life increases & 7 \\
\hline \multirow{4}{*}{ Integrations contributions to the school and the teachers } & Teachers find opportunities for self-improvement and renewal & 14 \\
\hline & Teachers are professionally satisfied & 2 \\
\hline & Attitudes of teachers and administrators change & 1 \\
\hline & Special education teachers' status will change & 1 \\
\hline \multirow{5}{*}{ Negative opinion } & $\begin{array}{l}\text { If physical and social arrangements are not provided, there will be negative } \\
\text { consequences }\end{array}$ & 9 \\
\hline & Financially difficult to apply & 3 \\
\hline & The negativities are caused by wrong applications & 3 \\
\hline & Negative results when peers do not receive the necessary explanation & 3 \\
\hline & If you have a competitive point of view, there will be a negative impact & 3 \\
\hline \multirow{5}{*}{ Negative opinion } & Developing perspective and employment are difficult & 2 \\
\hline & Teachers are not willing to do it since it does not bear return to the teacher & 1 \\
\hline & Individuals with severe disabilities cause a negative effect & 1 \\
\hline & Families who have children with disabilities shy away & 1 \\
\hline & $\begin{array}{l}\text { If there is no cooperation between the family and the school, there will be } \\
\text { negative results }\end{array}$ & 1 \\
\hline
\end{tabular}

Table 6 shows that the academics stated that integration will contribute positively to society, families, schools and teachers on various matters. Regarding integration's contributions to the society, A11 has stated the following, "If it can be applied in an ideal way, or in a way that will meets its purposes, I don't believe an integration application would yield negative results. We can say, especially peers with typical development will gain many social skills such as respecting differences, accepting people as they are, being happy and grateful for their current state, helping others etc." Regarding its contributions to the family, A19 has stated, "I think, since integration evaluates each child as an individual, and educates and develops them, it is very ideal for families too. Regarding its 
contributions to the school and teachers, A7 has stated, "As for the teachers, I think the teachers can find an opportunity to renew themselves with each new student profile they meet. However, if they resist the change, then they might be abusive to themselves, people around them, children with disabilities and other children as well. " A7 touches on the positive aspects of integration but does not forget to mention the possible negative outcomes if it is not thoroughly applied.

Table 7 presented below includes participants' opinions on the central theme of the research, "Opinions on the contribution of integration to students with typical development and students with disabilities."

Table 7. Academics' opinions on the positive or negative effects of integration on students with typical development and students with disabilities

\begin{tabular}{llr}
\hline Sub-Themes & Code & $\mathrm{f}$ \\
\hline \multirow{4}{*}{ Social contributions } & Accepting differences & 20 \\
& Being more tolerant and patient & 12 \\
& Social belonging-social acceptance & 11 \\
& Develops communication and social skills & 8 \\
& Creates a sense of sharing & 5 \\
& Enables the development of emotional and social intelligence & 1 \\
\hline & Peer teaching & 12 \\
& Modeling & 7 \\
& Psychological satisfaction & 3 \\
& It might have an influence on academic career choices & 2 \\
& Adaptations enable academic learning & 1 \\
& It will offer individually tailored educational opportunities for each child & 1 \\
\hline \multirow{2}{*}{ Negative opinion } & May be subject to peer rejection & 1 \\
& No academic contributions & 1 \\
\hline
\end{tabular}

Table 7 shows that the academics stated that integration has many academic and social contributions to students with disabilities and typically developing students. A18 has stated the following on its social contributions, "I think it definitely has social contributions. It teaches us to live with many individual or other differences, and it is effective on both parties." A1 has stated the following on its academic contributions, "It has many academic benefits. Because when you try to teach someone something they know nothing about, you learn more about it yourself."

Table 8 presented below includes participants' opinions on the central theme of the research, "Opinions on the scope and adequacy of academic studies on integration."

Table 8. Academics' opinions on academic studies on integration

\begin{tabular}{llc}
\hline Sub-Themes & Code & f \\
\hline \multirow{3}{*}{ The number of studies } & It is low & 10 \\
& There are few publications on secondary education & 1 \\
& There are no studies in different disciplinary areas & 1 \\
\hline & There are descriptive studies & 12 \\
Study method & The number of practice-based studies should increase & 12 \\
& Long-term and comprehensive studies are necessary & 4 \\
\hline \multirow{2}{*}{ Regarding Application } & Studies do not correspond with the society & 2 \\
& They fail to deliver a holistic conclusion & 1 \\
\hline Expertise & I don't think there are any contributions because the concepts are not understood thoroughly & 1 \\
\hline \multirow{2}{*}{ Other } & I haven't done much reading on integration & 6 \\
\hline
\end{tabular}

Table 8 shows the academics' various opinions on number of studies, study method, application phase and areas of expertise. Regarding the number of studies, A20 has stated, "Studies on integration are relatively new. There are a lot more studies on inclusion. Integration is just beginning to be a part of legal conversations; it is new in our 
lexicon and body of literature." Regarding the study methods, A8 has stated “...I think that maybe there should be more long-term, more comprehensive search conferences and applications that are ready to be turned into policies..." Regarding the application phase, A27 has stated, "I have not seen any application-oriented integration studies."

Table 9 presented below includes opinions on the central theme of the research, "Opinions on teacher adequacy and teacher training programs regarding the integration practices in Turkey."

Table 9. Academics' opinions on the adequacy of current teacher capabilities and teacher training programs

\begin{tabular}{|c|c|c|}
\hline Sub-Themes & Code & $\mathrm{f}$ \\
\hline \multirow{5}{*}{ Opinions and recommendations on teacher training program } & There is not enough content for integration & 18 \\
\hline & $\begin{array}{l}\text { All departments in the faculty of education should have courses } \\
\text { related to special education (ABA, IEP, Adaptation, Inclusion, } \\
\text { Learning Difficulties, Methods and Techniques used in Special } \\
\text { Education) }\end{array}$ & 15 \\
\hline & Two-hour classes are not enough & 12 \\
\hline & There should be a practice-based training process & 11 \\
\hline & Courses related to special education should be a part of other programs & 3 \\
\hline \multirow{4}{*}{ Opinions and recommendations on teacher training program } & Teacher selection system needs to change & 2 \\
\hline & Teachers should be taught adaptation and educational measurement & 2 \\
\hline & There's no teacher training system & 1 \\
\hline & Education faculties must be competitive & 1 \\
\hline \multirow{7}{*}{ Opinions and recommendations for currently working teachers } & Teachers must undergo serious in-service training & 13 \\
\hline & Teachers should be informed about integration & 8 \\
\hline & In-service training is not helpful & 5 \\
\hline & Online education platforms should be established & 3 \\
\hline & Teachers should be trained at certain intervals & 2 \\
\hline & Infrastructure shortages in schools affect teacher enthusiasm & 2 \\
\hline & School-based workshops should be held & 1 \\
\hline
\end{tabular}

Table 9 shows the academics' various opinions and recommendations on teacher training programs and currently working teachers. Regarding teacher training programs, A6 has stated, "We have recommended three courses on this topic in previous meetings. They were 'Preparing an individualized education plan,' 'Skill teaching' and 'Improving behaviour.'If teacher candidates take these three courses effectively... Of course, program adaptations are very important, teaching methods and applications should also be included in IEP, not just planning..." Regarding currently working teachers, A2 has stated, “...I think current teachers should undergo more serious in-service training."

Table 10 presented below includes participants' opinions on the central theme of the research, “Opinions on legal regulations for integration practices."

Table 10. Academics' opinions on legal regulations for integration practices

\begin{tabular}{llc}
\hline Sub-Themes & Code & $\mathrm{f}$ \\
\hline \multirow{2}{*}{ Laws are not applied } & Laws and regulations are adequate but not applied & 20 \\
& Serious sanctions must be imposed & 1 \\
\hline \multirow{2}{*}{ Legislation must be prepared } & There are no legal regulations on integration & 3 \\
& An integration regulation should be published & 1 \\
& An applicable legislation should be prepared in accordance with our country's culture & 1 \\
\hline Supervisors are uninformed & Supervisors should be knowledgeable on special education & 4 \\
\hline
\end{tabular}

Table 10 shows the academics' various opinions on laws for integration being sufficient but not implemented, the necessity of preparing legislation, and supervisors being uninformed. Regarding the laws not being implemented, A25 has stated, "Legal regulations exist, but I think these legal regulations do not reflect on many areas. They are not applied.” Regarding the opinions on necessity of legislation, A27 has stated, “...But I think before all else, a 
regulation should be published only under the name of integration." Regarding supervisors, A25 has stated, "Perhaps supervisors who will provide this supervision should be trained in the field of special education."

Table 11 presented below includes participants' opinions on the central theme of the research, "Opinions on the effects of support education services on the integration process."

Table 11. Academics' opinions on support education services' contributions to integration

\begin{tabular}{|c|c|c|}
\hline Sub-Themes & Code & $\mathrm{f}$ \\
\hline \multirow{10}{*}{$\begin{array}{l}\text { Opinions and recommendations on } \\
\text { support education services in } \\
\text { schools }\end{array}$} & Support education staff are inadequate & 12 \\
\hline & Support education should be provided in the classroom & 5 \\
\hline & There should be an interdisciplinary cooperation & 3 \\
\hline & $\begin{array}{l}\text { Support education services must be provided outside of school } \\
\text { hours }\end{array}$ & 3 \\
\hline & Support education rooms' functions should be checked carefully & 3 \\
\hline & Integration does not include support education & 2 \\
\hline & Support education should be given to the child & 1 \\
\hline & Support education is only effective when it follows the legislation & 1 \\
\hline & Support education rooms should be closed & 1 \\
\hline & Support education is the backbone of integration & 1 \\
\hline \multirow{6}{*}{$\begin{array}{l}\text { Opinions and recommendations on } \\
\text { support education that provides } \\
\text { Special Education and } \\
\text { Rehabilitation Center (SERC) }\end{array}$} & SERC and the school must be in touch & 5 \\
\hline & Two hours of training given at SERC is not enough & 4 \\
\hline & SERC staff is inadequate & 4 \\
\hline & Support education should be given in schools instead of SERC & 3 \\
\hline & SERC is not providing education that serves the purpose & 1 \\
\hline & SERC enabled children to leave the house & 1 \\
\hline
\end{tabular}

Table 11 shows the academics' various opinions and recommendations on support education services provided in schools and SERC. Regarding support education services provided at school, A18 has stated, "We do not provide support education in schools. We have applications such as resource room in schools but the thing is, teachers who can prepare and follow a program for students with disabilities or inclusion and integration students are not the ones teaching in these rooms. Instead, teachers who are responsible of less classes are doing the teaching." Regarding support education services provided by SERC, A25 has stated, "They are very disconnected from one another. There should be practices that keep the SERC in touch with the school."

Tables 12 and 13 presented below includes participants' opinions on the central theme of the research, "Opinions on educational and physical adaptations that can be followed in our schools for a successful integration." 
Table 12. Academics' opinions on physical adaptations that can be followed in our schools for a successful integration

\begin{tabular}{|c|c|c|}
\hline Sub-Themes & Code & $\mathrm{f}$ \\
\hline \multirow{6}{*}{ Physical adaptations for classes } & Accessible and attainable classes must be designed & 12 \\
\hline & Classroom's seating arrangements must change & 4 \\
\hline & Classrooms should be smaller & 3 \\
\hline & Classroom lighting should be decent & 3 \\
\hline & Acoustic arrangements needs to be done & 2 \\
\hline & The walls of the school and classroom should display children's creations & 1 \\
\hline \multirow{6}{*}{ Physical adaptations for schools } & The physical arrangements of schools should be suitable for all children & 10 \\
\hline & Adaptations vary based on type and level of disabilities & 10 \\
\hline & School gardens should be afforested and children should be able to touch the soil & 3 \\
\hline & Gaps should be covered with nets & 1 \\
\hline & Physical arrangements must be arranged to serve the purpose & 1 \\
\hline & Our schools are neither suitable for inclusion nor integration & 1 \\
\hline \multirow{3}{*}{ Other } & No extra regulation is needed if there is no one with physical disabilities & 1 \\
\hline & Making physical arrangements will not increase quality & 1 \\
\hline & Adaptation is out of the question; the system should be designed for all children in the first place & 1 \\
\hline
\end{tabular}

Table 12 shows the academics' various opinions and recommendations on schools and classrooms. Regarding the physical arrangements necessary in schools, A6 has stated, "If the child has additional disabilities, physical disabilities such as blindness or deafness, there are universal design principles that must be followed. I think it's very important that every school is accessible..." Regarding the physical adaptations necessary in classrooms, A17 has stated, "Even if the building stays the same, the teacher must make in-class adaptations. The most suitable environment should be chosen for the child's seat and his/her movement. Other children can be seated anywhere but these children should both be in reach of the teacher and also must be placed in a way that will not distract the rest of the class as much as possible." A16 has stated, "Inclusive education is not about physical or educational adaptations. The system must be designed from the beginning to meet every need and in a way that does not require adjustments or adaptations later. This is not up for debate."

Table 13. Academics' opinions on educational adaptations that can be followed in our schools for a successful integration

\begin{tabular}{|c|c|c|}
\hline Sub-Themes & Code & $\mathrm{f}$ \\
\hline \multirow{6}{*}{ Opinions and recommendations on course content } & $\begin{array}{l}\text { The content must be adapted accordingly to the child's disability during program } \\
\text { and evaluation processes }\end{array}$ & 15 \\
\hline & IEP must be executed well & 8 \\
\hline & We need to use technology very well & 2 \\
\hline & Continuous monitoring and evaluation are necessary & 1 \\
\hline & Program-based measurement must be done and requirements must be determined & 1 \\
\hline & Small arrangements are enough & 1 \\
\hline \multirow{3}{*}{ Opinions and recommendations on program content } & We need to create a flexible program & 2 \\
\hline & Educational content should be life-oriented & 1 \\
\hline & Curriculum should be designed in a way all students can learn & 1 \\
\hline \multirow{2}{*}{ Opinions and recommendations on materials } & Materials should be prepared in a way all students can learn & 2 \\
\hline & Teachers should design their own materials themselves & 1 \\
\hline \multirow{2}{*}{ Other } & Adaptation is out of the question; the system should be designed for all children & 1 \\
\hline & We either do not know how to adapt or just do not adapt & 1 \\
\hline
\end{tabular}

Table 13 shows the academics' various opinions and recommendations on course content, program and materials. Regarding the course content, A8 has stated, "That is our motto. There has to be educational adaptations for children. When it comes to inclusion and integration, if a child with a disability is placed in a program with children with typical development, the contents, plans, materials and evaluation processes has to be adapted accordingly. Legal regulation stipulates this." Regarding the program content, A1 has stated, "In other words, 
some regulations can only be made in line with the needs, laws are also things that are realized in line with needs, right? Therefore, it should be geared towards the needs, but it should be a little flexible in this, one should not look at everything from a fixed point of view. We should not look at it as just one thing, it should be diversified. If we diversify, we can prevent education and schools from becoming standardized. Schools should also change within themselves. Programs should change, there should not be a single type of curriculum, the curriculum should change, there can be the general framework, but the curriculum should change." Regarding the materials, A23 has stated, "Why do we teach material patterning, designing and technology in the special education department? In addition to the educational tools provided by the state, all teachers should teach in the most effective way by using technology with materials developed by themselves. So, the teacher has to put effort into the class."

Table 14 presented below includes opinions on the central theme, "Expectations and recommendations for a successful integration in our country."

Table 14. Academics' expectations and recommendations for integration to be successful in our country

\begin{tabular}{|c|c|c|}
\hline Sub-Themes & Code & $\mathrm{f}$ \\
\hline \multirow{3}{*}{$\begin{array}{l}\text { Opinions and recommendations } \\
\text { for academics }\end{array}$} & Academics should conduct practice-based studies & 14 \\
\hline & Academics should give seminars and trainings in schools & 4 \\
\hline & Academics' assessment requirements must change & 1 \\
\hline \multirow{15}{*}{$\begin{array}{l}\text { Opinions and recommendations } \\
\text { for the Ministry of National } \\
\text { Education (MEB) and other } \\
\text { ministries }\end{array}$} & MEB must take steps about supervision and sanction & 9 \\
\hline & Public awareness must be raised through cooperation of ministries & 8 \\
\hline & Senior decision makers and institutions should carry out coordinated work & 7 \\
\hline & Senior managers must plan the integration process & 5 \\
\hline & MEB should start with pilot applications & 3 \\
\hline & Teachers' working conditions must be improved & 3 \\
\hline & MEB should do project work for integration & 3 \\
\hline & MEB and Council of Higher Education (YOK) should cooperate & 2 \\
\hline & Ministries should facilitate permits for research & 2 \\
\hline & There should be a competitive and flexible education system & 2 \\
\hline & Our education system should be planned for internal supervision & 1 \\
\hline & General education should be organized before all else & 1 \\
\hline & Special education courses should be taught in all departments of universities & 1 \\
\hline & Schools applying integration should be rewarded & 1 \\
\hline & Diagnosis and evaluation should be left to Counseling and Research Center & 1 \\
\hline \multirow{2}{*}{$\begin{array}{l}\text { Opinions and recommendations } \\
\text { for teachers and administrators }\end{array}$} & $\begin{array}{l}\text { Administrators must be willing, monitoring and supervising throughout the integration } \\
\text { process }\end{array}$ & 15 \\
\hline & Teachers should teach by adapting & 7 \\
\hline \multirow{6}{*}{$\begin{array}{l}\text { Opinions and recommendations } \\
\text { for families }\end{array}$} & Families should know their legal rights and be demanding & 7 \\
\hline & All families should be informed about integration & 7 \\
\hline & Families must be participants & 5 \\
\hline & Families of children with typical development should act conscientiously and ethically & 2 \\
\hline & We must change the families first & 1 \\
\hline & Families of children with disabilities must follow the guidance of experts & 1 \\
\hline Other & All parties should cooperate & 5 \\
\hline
\end{tabular}

Table 14 shows the participants' various recommendations to academics, ministries, teachers, administrators and families. Regarding academics, A20 has stated, "We experts need to go to the application environments of professors at the university. If we really want to give and do something about this issue, we should put aside writing articles for conferences or making translations at our desk, and definitely go see to the application environments." Regarding the ministries and senior decision makers, A11 has stated, "All administrators from the Ministry of National Education to the provincial directorates of national education, district directorates of national education and school principals must truly believe in this issue. The reason for applying this should not be that it is a legal requirement, but that they are convinced of its benefits and have a tendency to apply it." Regarding teachers and administrators, A17 has stated, "Administrators must have a good command of legal rights. They should not have an attitude of 'they can follow it if they like, and if not, that's fine.' To be frank, it is not something where they can 
decide by taking the initiative..." A4 on the same topic has stated, "Teachers' suggestions should be taken seriously, teachers should be encouraged. Because teaching is no longer a prestigious job. Teachers both earn less financially and are not honored. Teachers should be honored..." Regarding families, A17 has stated, "First of all, families must know their legal rights very well. The family must be demanding with the school about this. They must cooperate with the school administration in all cases regarding their child's rights, and must ensure that the school administration meets these rights..." Regarding the parties of integration, A8 has stated, "In other words -it's a very cliché and an impolite expression but- they should all step up to the plate. They can't just expect the other parties to be excluded."

\section{Discussion}

This study reveals the opinions of academics who train special education teachers on integration applications in Turkey and their recommendations for successful integration. In general, the research results present academics share the opinion that integration is not applied today and that the necessary infrastructure for its application does not exist. They emphasize that the concepts of inclusion and integration have different applications, and yet the concepts are used interchangeably. They state that when integration is fully applied, it will positively contribute to society, families, teachers, individuals with disabilities, and individuals with typical development. They note that academic studies on integration are at a descriptive level and that practice-based studies are necessary. They remark that there are problems with the implementation of laws and regulations about integration applications. They state that teacher training programs should be revised from an integration perspective and that current teachers should undergo in-service training. They point out that the staff involved in support education is inadequate and that the support services provided to the child should become more qualified. They emphasize that physical and educational arrangements should be designed in a way all students can learn. Finally, academics make various recommendations to ministries, academics, administrators, teachers, and families.

In this study, participants voice the physical, conceptual, staff-related, and applicational problems with the current state of integration. Similarly, Karakütük et al. (2012) found in their study that the physical conditions of schools were inadequate and that schools had not reached the desired level. The phrases "integration/inclusion" are used interchangeably in literature and legislation (Kargın, 2018; MEB, 2017; Sarı \& Pürsün, 2016; TOHUM \& ERG, 2011). Keser and Düzkantar (2019) emphasized that the definition of integration is based on inclusion, but integration should be defined separately and clearly. Studies on inclusion show that teachers are not knowledgeable about inclusion applications (Batu et al., 2004; Demirezen \& Akhan, 2015; Vural \& Y1kmış, 2008; Zeybek, 2015). Considering that integration is a step beyond inclusion, we can conclude that teachers have insufficient knowledge of integration. Studies have shown that teacher attitudes are negative and inadequate about acceptance of students with disabilities (Cagran \& Schmidt, 2011; Chiner \& Cardona, 2013; De Boer et al., 2011; Emam \& Mohamed, 2011; Hwang \& Evans, 2011; Saloviita, 2020; Zeybek, 2015; Zwane \& Malale, 2018).

The study's findings reflect academics statements about integration covering all disability groups, being community-based, and the learning environment being adapted to the child, while inclusion covering moderate intellectual disability, the child being adapted to the environment, and being school-based. A literature examination of the learning environments of children with disabilities shows that only moderately disabled children receive a full-time or part-time inclusive education in general education classrooms that provide the necessary arrangements (Ataman, 2003; Cavkaytar, 2018; Çolak, 2019; Melekoglu, 2018; Odluyurt, 2019). Integration, on the other hand, is aimed at providing each child an equal education with their peers and their effective participation in the social, cultural, political, and economic life of the society in which they live (Corbett, 2002; Feuser, 2002; Thomas et al., 2001; Sarı \& Pürsün, 2016; Stojik, 2009). In this context, we can say that integration is a broader concept that also includes inclusion.

This study has found that most academics think integration application will pave the way for more social acceptance of individuals with disabilities and a positive perspective shift in society. They stress that the families' burdens will decrease and their quality of life will increase. They add that teachers will have the opportunity to develop and renew themselves; students will learn to be more tolerant and patient. They state that peer teaching and modeling will provide academic contributions. Odluyurt (2015) noted that integration practices tend to be respectful, sensitive, and tolerant of individual differences in the long term as a result of typically developing children and their families having positive attitudes. Inclusion contributes positively to society, students with disabilities, students with typical development, families, and teachers (Çolak, 2019; Kargın, 2018). There is a belief that the positive contribution of inclusion applications will be provided more comprehensively through integration to all these parties.

It is believed that information deficiency is the reason behind teachers' reluctance towards having students with 
disabilities in their classes, and the necessary educational and support services can eliminate their negative attitude (Batu et al., 2014; Gürsoy et al., 2019; Sharma et al., 2012; Yıkmış, 2006; Zeybek, 2015). It seems that teachers who have experience with integration or take courses related to integration are more amenable to integration practices (Cagran \& Schmidt, 2011; De Boer et al., 2011). Evidently, candidate teachers who take inclusion courses or are informed about inclusion have a more positive attitude about its applications (Dolapc1 \& Yildiz Demirtas, 2016; Gözün \& Yıkmış, 2004; Orel et al., 2004; Sarı \& Bozgeyikli, 2003). Similarly, it is expected that the attitudes of teachers who are informed about integration practices will change positively.

According to the findings, most academics note that laws and regulations on integration practices are sufficient, but there are problems with their applications. As for supervision, they stress that supervisors do not have sufficient knowledge of special education and integration. The literature shows that the supervisors who inspect special education institutions have insufficient knowledge of special education (Gözün \& Yıkmış, 2004; Keser, 2016). In this sense, the preparation of legal regulations is not sufficient in itself, and their application levels should be strictly inspected. It is important that the supervisors are knowledgeable and equipped about integration.

According to the study's findings, the staff employed in schools and support services provided by SERC are insufficient. Also, support education should be provided outside school hours and in cooperation. SERC and the schools must be in touch. Besides, two hours of weekly education provided at SERC is insufficient. The dissemination of support education rooms in schools and their active and functional use positively affects inclusion applications (Yılmaz \& Batu, 2016). Inclusion applications provide support education services in the forms of consultant-assisted general education classes, special education teacher-assisted general education classes and general education classes that include an education assistant (Kargın, 2009). It is believed that students attending support education rooms outside of school hours or provision of support education in the classroom is more in line with the philosophy of integration applications. In his study, Keser (2016) concluded that support education services provided to individuals with disabilities are far from integration practices and that services provided in SERC are insufficient for support education services in integration applications. This study's conclusion about the insufficiency of school staffs and SERC is consistent with the literature (Isman, 2009; Kargin, 2009; Y1lmaz \& Batu, 2016).

According to the results of this study, participants express that it is obligatory to adapt the content, material, program, and evaluation process for the child's disability, and adaptations must differ from student to student. In 2013 Ministry of National Education published "Strengthening Turkey's Special Education Project, Barrier-Free School Model: A Road Map for Standards and Performance Indicators," introduced the concept of "barrier-free school" within the scope of integration and defined it as a model to effectively integrate students with disabilities in social life by starting at the early stages. The study stated that the necessary physical arrangements should be made within or around the schools and that the student should have access to the school. The same project emphasizes that the materials should be prepared in accordance with different learning styles and individual differences of all students, the curriculum should be adapted according to the developmental characteristics and needs of the students, and the assessment and evaluation should be done by taking the developmental characteristics of the student into consideration. Creating the necessary infrastructure to apply the "Barrier-Free School Model" of the Ministry and making schools accessible to all will be an important progress for integration. Special Education Services Regulation emphasized that IEP is essential to meet the needs of students with disabilities (MEB, 2017), but Zeybek (2015) has revealed that teachers do not prepare the IEP. Another critical problem in schools is the lack of materials (Eratay et al., 2012). In this sense, it is necessary to provide teachers with the training they need and to eliminate material deficiencies.

According to the research results, academics have expectations and suggestions for some parties to achieve a successful integration. They state that academics should conduct practice-based studies and seminars or training in schools. They state that ministries should inform the community in cooperation and that senior managers should work on planning. They discuss improving the working conditions of teachers and preparing and carrying out projects. They state that the school administration should be willing, demanding, and monitoring integration applications and that teachers should make adaptations. They point out that families should be demanding, participatory, and knowledgeable about legal rights. Güner-Yıldız et al. (2016), in their research where they bibliometrically examined articles on special education published in five Turkish journals that had been included in the Social Sciences Citation Index (SSCI) and concluded that only 113 of the 4478 articles were related to special education. The number of articles shows that articles related to special education are very few, meaning the number of studies conducted on integration is also very small. One of the duties of the Ministry of National Education in the Decree-Law on the Organization and Duties of the Ministry of National Education is to determine educational policies for students with disabilities in cooperation with other ministries. Also, it is among the duties 
of the ministry to educate all students in accordance with the requirements of the current age. Defining and meeting the needs of families is essential for the education and development of a child with disabilities (Aksoy, 2013). It is believed that informing families about integration and defending their rights will positively affect integration practices. Teachers and education must be above politics, and change must be carried out with plans. It is necessary to take the opinion of all parties throughout the changes. Besides, physical and economic conditions need to be improved (Şahin \& Demirel, 2019). Çınkır and Çetin (2010), as a conclusion of their study, suggested teachers should be provided with better working conditions and environments.

In conclusion, we can say that integration can be applied in a multidimensional way; all parties must fulfill their responsibilities, and the necessary arrangements should be carried out. In the light of the findings obtained in the study, we can conclude that all schools should be adjusted to be accessible to all students through physical adaptations. The curriculum should be designed and varied in a way all students can learn. After the courses related to integration are included in all departments of education faculties, newly trained teachers should graduate with a knowledge of the integration applications. Support education services should be provided competently and following the philosophy of integration. It is necessary to inspect whether legal regulations are applied.

This study features the opinions recommendations of academics who train special education teachers regarding a successful integration application in our country. The study's findings suggest that a similar study can be carried out with the other parties of integration, such as special education teachers, class teachers, field teachers, administrators, and senior managers working in schools. Practice-based, comprehensive, and long-term experimental studies can be conducted on integration applications using different research methods. The findings of the study can be helpful when arranging educational environments.

\section{References}

Aksoy, V. (2013). Aileye ilişkin bilgilerin toplanması ve değerlendirme. In A. Cavkaytar (Ed.), Özel eğitimde aile eğitimi ve rehberliği [Family education and guidance in special education] (pp. 106-108). Vize Yayıncılık.

Ataman, A. (2003). Özel gereksinimli çocuklar ve özel eğitim. In A. Ataman (Ed.), Özel gereksinimli çocuklar ve özel eğitime giriş [Children with special needs and admission to special education] (pp. 13-28) Gündüz Eğitim ve Yayıncılık.

Ataman, A. (2017). Özel eğitimin temelleri. In A. Ataman (Ed.), Temel eğitim öğretmenleri için kaynaştırma uygulamalarl ve özel eğitim [Mainstreaming practices and special education for primary education teachers] (pp. 3-21) Vize Yayınc1lik.

Bakkaloglu, H., Sucuoğlu, B., \& Özbek, A. B. (2020). Okul öncesinde özel gereksinimli olan ve normal gelişen çocukların sosyal kabul düzeylerinin incelenmesi [Examining social acceptance levels of children with special needs and typical developmentin preschool classrooms]. Elementary Education Online, 18(2), 521-538. https://doi.org/10.17051/ilkonline.2019.562011

Balaban Salı, J. (2015). Sosyal bilimlerde araştırma yöntemleri. In A. Şimşek (Ed.), Verilerin toplanması [Collection of data] (pp. 134-161). Anadolu Üniversitesi Yayınları.

Balc1, A. (2018). Sosyal bilimlerde araştırma yöntem, teknik ve ilkeler [Research methods, techniques and principles in social sciences]. Pegem Akademi.

Batu, S., \& Kırcaali-İftar, G. (2007). Kaynaştırma [Mainstreaming]. Kök Yayıncılık.

Batu, S., Çolak, A., \& Odluyurt, S. (2014). Özel gereksinimli çocukların kaynaştırılması [Integration of children with special needs]. Vize Yayıncılık.

Batu, S., Kırcaali-İftar, G., \& Uzuner, Y. (2004). Özel gereksinimli öğrencilerin kaynaştırıldığı bir kız meslek lisesindeki öğretmenlerin kaynaştırmaya ilişkin görüş ve önerileri [Opinions and suggestions of teachers in a girls' vocational high school where students with special needs are integrated]. Ankara Üniversitesi Ë̆itim Bilimleri Fakültesi Özel Eğitim Dergisi, 5(02), 33-50. https://doi.org/10.1501/Ozlegt_0000000082

Bredtmann, J., Otten, S., \& Vonnahme, C. (2021). Linguistic diversity in the classroom, student achievement, $\begin{array}{llll}\text { and } & \text { social integration. Education } & \text { Economics, }\end{array}$ https://doi.org/10.1080/09645292.2020.1866499

Cagran, B., \& Schmidt, M. (2011). Attitudes of Slovene teachers towards the inclusion of pupils with different types of special needs in primary school. Educational Studies, 37(2), 171-195. https://doi.org/10.1080/03055698.2010.506319

Cavkaytar, A. (2018). Özel eğitim alanı. In A. Cavkaytar, \& D. Tekin Ersan (Eds.), Özel eğitim ve kaynaştırma 
[Special education and mainstreaming] (pp. 8-23). Eğiten Kitap.

Chiner, E., \& Cardona, M. C. (2013). Inclusive education in Spain: How do skills, resources, and supports affect regular education teachers' perceptions of inclusion? International journal of inclusive education, 17(5), 526-541. https://doi.org/10.1080/13603116.2012.689864

Civelek, A. (1991). Zihinsel özürlü çocukların eğitiminde bütünleştirme yöntemi (amacı, türleri, gerektirdiği koşullar) [Integration method in the education of mentally handicapped children (purpose, types, conditions)]. Eğitim ve Bilim, 15(82), 47-53.

Corbett, J. (2002). Supporting inclusive education. Routledge. https://doi.org/10.4324/9780203453339

Creswell, J. W. (2013). Steps in conducting a scholarly mixed methods study. DBER Speaker series. University of Nebraska Discipline-Based Education Research Group (Online)

Çınkır, Ş., \& Çetin, S. K. (2010). Öğretmenlerin okullarda mesleki çalışma ilişkileri hakkındaki görüşleri [Teachers opinions about the professional working relationships in schools]. Kuram ve Uygulamada Ĕgitim Yönetimi, 3(3), 353-371.

Çolak, A. (2019). Özel eğitim alanı, kaynaştırma, bütünleştirme/kapsayıcı eğitim, bireyselleştirilmiş eğitim programı (BEP). In Y. Ergenekon (Ed.), Kaynaşstırmada başarı için birlikte yürüyelim: yardımcı destek personel eğitimi el kitabı [Let's walk together for success in mainstreaming: Helpful support staff training handbook.] (p. 24). Sabancı Vakfi.

De Boer, A., Pijl, S. J., \& Minnaert, A. (2011). Regular primary schoolteachers' attitudes towards inclusive education: A review of the literature. International Journal of Inclusive Education, 15(3), 331-353. https://doi.org/10.1080/00313831.2018.1541819

Demirezen, S., \& Akhan, N. E. (2015). Sosyal bilgiler öğretmenlerinin kaynaştırma uygulamalarına yönelik görüşlerinin ve deneyimlerinin incelenmesi [Examination of the view points and experiences of social studies teachers related to the implementation of inclusion]. Milli Eğitim Dergisi, 47(219), 57-88.

Derzhavina, V. V., Nikitina, A. A., Makarov, A. L., Piralova, O. F., Korzhanova, A. A., Gruver, N. V., \& Mashkin, N. A. (2021). Inclusive education importance and problems for students social integration. Propósitos y Representaciones, 9(SPE3), 1130. https://doi.org/10.20511/pyr2021.v9nSPE3.1130

Desombre, C., Lamotte, M., \& Jury, M. (2019). French teachers' general attitude toward inclusion: The indirect effect of teacher efficacy. Educational Psychology, 39(1), 38-50. https://doi.org/10.1080/13603116.2020.1821451

Dolapcı, S., \& Demirtaş, V. Y. (2016). Öğretmen adaylarının öz-yeterlilik algıları ve kaynaştırma eğitimine bakış açıları [Prospective teachers' self-efficacy perceptions and perspectives on inclusive education]. Batı Anadolu Eğitim Bilimleri Dergisi, 7(13), 141-160.

Eğitimde Reform Girişimi \& Tohum Otizm Vakfı [The Education Reform Initiative \& Tohum Autism Foundatıon]. (2011). Türkiye'de kaynaştırma/bütünleştirme yoluyla eğitim: Politika ve uygulama önerileri [Turkey Mainstreaming/Inclusion through education: Policy and practice recommendations]. Retrieved from http://www.egitimreformugirisimi.org/wp-content/uploads/2017/03/KaynastirmaPolitika Raporu.pdf

Emam, M. M., \& Mohamed, A. H. H. (2011). Preschool and primary school teachers' attitudes towards inclusive education in Egypt: The role of experience and self-efficacy. Procedia-Social and Behavioral Sciences, 29(2011), 976-985. https://doi.org/10.9782/19-00001

Eratay, E., Çifçi-Tekinaslan, İ., \& Yıkmış, A. (2012). Zihin engelliler sınıf öğretmenlerinin eğitim uygulama okulu programına ve öğretimde kullandıkları yöntemlere ilişkin görüşleri [Opinions of the class teachers of mentally disabled on the education application school program and the methods used in teaching]. $A \dot{I} B \ddot{U}$ Sosyal Bilimler Enstitüsü Dergisi, 12(20), 137-158. https://doi.org/10.11616/AbantSbe.293

Feuser, G. (2002). Von der integration zur inclusion [Paper presentation]. 6th Allgemeinpädagogischen Tagung, Curative Education Society of Lower Austria, Baden, Austria.

Glesne, C. (2015). Becoming qualitative researchers: An introduction. Pearson.

Gözün, Ö., \& Yıkmış, A. (2004). Öğretmen adaylarının kaynaştırma konusunda bilgilendirilmelerinin kaynaştırmaya yönelik tutumların değişimindeki etkinliği [The effect of informal program for prospective teachers about mainstreaming on changing their attitudes toward mainstraming education]. Ankara Üniversitesi Eğitim Bilimleri Fakültesi Özel Eğitim Dergisi, 5(2), 65-77. https://doi.org/10.1501/Ozlegt_0000000081 
Gümüşkaya, Ö. (2018). Bütünleştirmede işbirliği: Tanımı, önemi, türleri. In M. Çitil (Ed.), Özel eğitimde bütünleştirme [Inclusion in special education] (pp. 75-101). Vize Akademik.

Güner-Yıldız, N., Melekoğlu, M. A., \& Paftalı, A. T. (2016). Special education research in Turkey. Elementary Education Online, 15(4), 1076-1089. https://doi.org/10.17051/io.2016.06677

Gürsoy, F., Aral, N., Öz, N. S., \& Aysu, B. (2019). Öğretmenlerin kaynaştırma/bütünleştirme uygulaması hakkindaki görüşleri: bir metafor çallşması [Teachers' views about inclusive/ntegration practices: A metaphor study] [Sözlü bidiri]. 3. Uluslararası Öğretmen Eğitimi ve Akreditasyon Kongresi, TED Üniversitesi, Ankara, Türkiye.

Hammeken, P. A. (2000). Inclusion 450 strategies for success-a practical guide for all educators who teach students with disabilities, ideal for setting up an inclusive education program, strategies for making accommodations plus practical forms. Pearson Education Inc.

Hernandez, D. A., Hueck, S., \& Charley, C. (2016). General education and special education teachers' attitudes towards inclusion. Journal of the American Academy of Special Education Professionals, 79, 93.

Hwang, Y. S., \& Evans, D. (2011). Attitudes towards inclusion: Gaps between belief and practice. International Journal of Special Education, 26(1), 136-146.

İşman, H. (2009). Engellilerin eğitimine yönelik bir politika aracı olarak özel özel eğitim kurumlarının eğitimde eşitlik bağlamında değerlendirilmesi [Evaluation of private education institutions in context of educational equity intended for diasabled training as means of policy] (Tez Numarası: 279958) [Yüksek lisans tezi, Ankara Üniversitesi]. Yükseköğretim Kurulu Ulusal Tez Merkezi.

Karakütük, K., Tunç, B., Bülbül, T., Özdem, G., Tasdan, M., Çelikkaleli, Ö., \& Bayram, A. (2012). The adequacy of physical conditions of public high schools in Turkey according to their sizes. Journal of Faculty of Educational Sciences, 45(2). https://doi.org/10.1501/Egifak_0000001259

Kargın, T. (2009). Özel gereksinimi olan öğrencilerin yerleştirilmesi ve BEP. In A. G. Akçamete (Ed.), Özel eğitim [Special education] (pp. 77-109). KÖK Yayınc1lık

Kargın, T. (2018). Kaynaştırma eğitimi. In N. Baykoç (Ed.), Öğretmenlik programları iç̧in özel eğitim ve kaynaştırma [Special education and mainstreaming for teaching programs] (pp. 66-88). İzge Yayınc1lık.

Keser, F. (2016). Özel gereksinimli bireylerin aldıkları destek hizmetlerin bütünleştirme uygulamaları açısından incelenmesi [An investigation of support services for individuals with special needs regarding inclusive practices] (Tez Numarası: 429932) [Yüksek Lisans Tezi, Bolu Abant İzzet Baysal Üniversitesi]. Yükseköğretim Kurulu Ulusal Tez Merkezi.

Keser, F., \& Düzkantar, A. (2019). Bir alanyazın taraması: Öğretmen yeterliliklerinin bütünleştirme uygulamaları açısından incelenmesi [A literature review: An investigation of teacher qualifications for inclusive applications]. Journal of International Social Research, 12(65), 841-849. https://doi.org/10.17719/jisr.2019.3496

Ketenoğlu Kayabaşı, Z. E. (2020). Teachers' opinions on inclusive education. International Journal of Psychology and Educational Studies, 7(4), 27-36. https://doi.org/10.17220/ijpes.2020.04.003

Melekoğlu, M.A. (2018). Özel eğitimde yerleştirilme yaklaşımları ve en az sınırlandırılmış eğitim ortamı. In M. Çitil (Ed.), Özel eğitimde bütünleştirme [Inclusion in special education] (pp. 21-37). Vize Akademik.

Metin, N. (2012). Özel gereksinimli çocuklar. In N. Metin (Ed.), Özel gereksinimli çocuklar [Children with special needs] (pp.1-10). Maya Akademi.

Miles, M, B., \& Huberman, A. M. (1994). Qualitative data analysis: An expanded sourcebook (2nd ed). Sage.

Millı̂ Eğitim Bakanlığı [Ministry of National Education]. (2013). Bütünleştirme kapsamında eğitim uygulamaları [Educational practices within the scope of inclusion]. Retrieved from https://orgm.meb.gov.tr/kitaplar/Butunlestirme_Kapsaminda_Egitim_Uygulamalari_Ogretmen_Kilavuz_Kit abi.pdf

Millî Eğitim Bakanlığı [Ministry of National Education]. (2013). Türkiye'de özel eğitimin güçlendirilmesi projesi engelsiz okul modeli: standartlar ve performans göstergeleri yol haritası [Strengthening the special education project in Turkey unobstructed school model: standards and performance indicators roadmap]. Retrieved from https://orgm.meb.gov.tr/meb_iys_dosyalar/2013_09/04115200_engelsizokulmodeliyolharita s.pdf 
Millî Eğitim Bakanlığı [Ministry of National Education]. (2017). Kaynaştırma/bütünleştirme yoluyla eğitim uygulamalarl genelgesi [Circular on education practices through mainstreaming]. Retrieved from https://orgm.meb.gov.tr/meb_iys_dosyalar/2017_09/21112929_kaynastirma_genelge.pdf

Nichols, S., \& Sheffield, A. N. (2014). Is there an elephant in the room? Considerations that administrators tend to forget when facilitating inclusive practices among general and special education teachers. National Forum of Applied Educational Research Journal, 27(1/2), 31-44.

Odluyurt, S. (2015). Kaynaştırma eğitiminde uygulamalı davranış analizi [Applied behavior analysis in mainstreaming education]. Eğiten Kitap.

Odluyurt, S. (2019). Kaynaştırma ve bütünleştirme nedir? In E. S. Batu (Ed.), Kaynaştırma ortamında uygulamalar [Applications in an integrated environment) (pp. 3-12). Vize Akademik.

Okech, J. B., Yuwono, I., \& Abdu, W. J. (2021). Implementation of inclusive education practices for children with disabilities and other special needs in uganda. Journal of Education and e-Learning Research, 8(1), 97-102. https://doi.org/10.20448/journal.509.2021.81.97.102

Orel, A., Zerey, Z., \& Töret, G. (2004). Sınıf öğretmeni adaylarının kaynaştırmaya yönelik tutumlarının incelenmesi [Examination of the classroom teacher candidates' attitudes towards inclusion]. Ankara Üniversitesi Eğitim Bilimleri Fakültesi Özel Eğitim Dergisi, 5(01), 23-33. https://doi.org/10.1501/Ozlegt_0000000076

Robinson, G. (2017). Perceptions and attitudes of general and special education teachers toward collaborative teaching (Doctoral dissertation). Retrieved from ProQuest Dissertations and Theses database (UMI No.10622862)

Salend, J. S. (2008). Creating inclusive classrooms: Effective and reflective practices 4. PrenticeHall.

Saloviita, T. (2020). Attitudes of teachers towards inclusive education in Finland. Scandinavian Journal of Educational Research, 64(2), 270-282. https://doi.org/10.1080/00313831.2018.1541819

Sarı, H., \& Bozgeyikli, H. (2003). Öğretmen adaylarının özel eğitime yönelik tutumlarının incelenmesi: Karşılaştırmalı bir araştırma [Analysis of teacher candidates attitude to special educatıon: A comparative research]. Selçuk Üniversitesi Sosyal Bilimler Enstitüsü Dergisi, 9, 183-203.

Sarı, H., \& Pürsün, T. (2016). Özel eğitimde etkili kaynaştırma bütünleştirme [Effective mainstreaming inclusion in special education]. Atlas Yayınevi.

Saygın, M. (2015). Mesleki eğitimde bütünleştirme uygulamalarının değerlendirilmesi (Sincan IMKB Ticaret Meslek Lisesi örneği) [The evaluation of the application of inclusion in vocational training (The example of Sincan IMKB Vocational High School of Trade)] (Tez Numaras1: 378260) [Yüksek Lisans Tezi, Gazi Üniversitesi]. Yükseköğretim Kurulu Ulusal Tez Merkezi.

Sharma, U., Loreman, T., \& Forlin, C. (2012). Measuring teacher efficacy to implement inclusive practices. Journal of Research in Special Educational Needs, 12(1), 12-21. https://doi.org/10.1111/j.1471-3802.2011.01200.x

Solis, M., Vaughn, S., Swanson, E., \& Mcculley, L. (2012). Collaborative models of instruction: The empirical foundations of inclusion and co-teaching. Psychology in the Schools, 49(5), 498-510. https://doi.org/10.1002/pits.21606

Stojić, T. (Ed.). (2009). A guide for advancing inclusive education practice. Fund for an open Society.

Sucuoğlu B. (2006). Etkili kaynaştırma uygulamaları [Effective mainstreaming practices]. Ekinoks Yayınları.

Şahin, S., \& Demirel, Ö. A. (2019). Türkiye'de eğitimde değişim ihtiyaçlarına, engellerine ve değişime yön vermeye ilişkin öğretmen görüşleri [Teacher ideas on needs, obstacles and guiding of education changing in Turkey]. Dokuz Eylül Üniversitesi Buca Eğitim Fakültesi Dergisi, 2(48), 88-106.

Thomas, G., Walker, D., \& Webb, J. (2001). The making of the inclusive school. Routledge.

UNESCO. (1994). The Salamanca statement and framework for action on special needs education. Paris, France: United Nations Educational, Scientific and Cultural Organization.

UNESCO. (2006). United nations convention on the rights of persons with disabilities. New York, NY: United Nations.

Vaughn, S., Bos, C., \& Schumm, J. S. (2000). Teaching exceptional diverse, and at risk students in the general elementary classroom. Allyn \& Bacon 
Vural, M., \& Yıkmış, A. (2008). Kaynaştırma sınıfı öğretmenlerinin öğretimin uyarlanmasına ilişkin yaptıkları çalışmaların belirlenmesi [A determination of the studies made on instructional adapdation by inclusive classroom teachers]. Abant İzzet Baysal Üniversitesi Eğitim Fakültesi Dergisi, 8(2), 141-159.

Walker, D. (1995). Postmodernity, inclusion and partnership (Unpublished MEd dissertation). Milton Keynes: Open University.

Yıkmış, N. (2006). Il Milli Eğitim yöneticilerinin kaynaştırma uygulamalarına ilişkin görüş ve önerileri [The views and the suggestions of the district education diroctors regarding the mainsreaming practices] (Tez Numarası: 189613) [Yüksek Lisans Tezi, Bolu Abant İzzet Baysal Üniversitesi]. Yükseköğretim Kurulu Ulusal Tez Merkezi.

Yıldırım, A., \& Şimşek, H. (2018). Sosyal bilimlerde nitel araştırma yöntemleri [Qualitative research methods in the social sciences]. Seçkin Yayıncıllk.

Yılmaz, E., \& Batu, E. S. (2016). Farklı branştan ilkokul öğretmenlerinin bireyselleştirilmiş eğitim programı, yasal düzenlemeler ve kaynaştırma uygulamaları hakkındaki görüşleri [Opinions of primary school teachers about individualized education programme, legal regulation and inclusion implementation]. Ankara Üniversitesi Eğitim Bilimleri Fakültesi Özel Eğitim Dergisi, 17(03), 247-268. https://doi.org/10.21565/ozelegitimdergisi.267316

Yükseköğretim Kurulu [Concil of Higer Education]. (2018). Yeni öğretmen yetiştirme lisans programları [New teacher training undergraduate programs]. https://www.yok.gov.tr

Zeybek, Ö. (2015). Illköğretim okullarındaki İngilizce öğretmenlerinin kaynaştırma uygulamalarına ilişkin görüş ve önerileri [Opinions and suggestions of english teachers in primary schools about inclusive education] (Tez Numarası: 388883) [Yüksek Lisans Tezi, Anadolu Üniversitesi]. Yükseköğretim Kurulu Ulusal Tez Merkezi.

Zigmond, N. P., \& Kloo, A. (2017). General and special education are (and should be) different. In J. M. Kauffman, D. P. Hallahan, \& P. C. Pullen (Eds.), Handbook of special education (pp. 160-170). Routledge. https://doi.org/10.4324/9781315517698-21

Zwane, S. L., \& Malale, M. M. (2018). Investigating barriers teachers face in the implementation of inclusive education in high schools in Gege branch, Swaziland. African Journal of Disability (Online), 7, 1-12. https://doi.org/10.4102/ajod.v7i0.391

\section{Note}

Note 1. This study is based on the master thesis of the first author under the supervision of Assoc. Prof. Ahmet Yıkmış presented to the Special Education Department, Bolu Abant İzzet Baysal University. It was also presented in the 30 th National Special Education Congress.

\section{Copyrights}

Copyright for this article is retained by the author(s), with first publication rights granted to the journal.

This is an open-access article distributed under the terms and conditions of the Creative Commons Attribution license (http://creativecommons.org/licenses/by/4.0/). 